\title{
Unit per Square Meter
}

National Cancer Institute

\section{Source}

National Cancer Institute. Unit per Square Meter. NCI Thesaurus. Code C67467.

A dose calculation unit expressed as a number of arbitrary units of substance per one square meter of a body surface area. 